\title{
Factors Affecting The Participation Of Husband \\ To be acceptors of contraception \\ In BPM N Banjarmasin
}

Ika Mardiatul Ulfa ${ }^{1 *}$

${ }^{1}$ Academy of Midwifery Sari Mulia, Banjarmasin Indonesia

*ikamardiatululfa86@gmail.com

Dwi Sogi Sri Redjeki ${ }^{2}$

${ }^{2}$ STIKES Sari Mulia Banjarmasin Indonesia

Dwi_sogi_sri_redjeki@stikes

Henny Auliana ${ }^{3}$

${ }^{3}$ Department of Science Midwifery Sari Mulia Banjarmasin

\begin{abstract}
Objective: Knowing Factors Affecting The Participation Of Husband To Be Acceptors Contraception In BPM N Banjarmasin

Method: This research is an analytic survey with cross-sectional approach. Samples totaling 49 people were taken using accidental sampling technique. Data were analyzed by chi-square with $95 \%$ degree of trust.

Results: The highest age was 25-50 years of age 31 people $(63.3 \%)$, based on education 22 people (44.9\%) medium-educated, based on employment 44 people $(89.8 \%)$ respondents work, based on income 26 people $(53,1 \%)$ earning <Rp 2,085,000 / month, based on knowledge of 19 people (38.8\%) knowledgeable enough, and based on participation 37 people $(24.5 \%)$ did not participate as family planning acceptors. There was influence of age with participation $(p=0,041)$, influence of education with participation $(\mathrm{p}=0,041)$, no influence of work with participation $(\mathrm{p}=0,179)$, no influence of income with participation $(\mathrm{p}=0,092)$ with participation $(\mathrm{p}=0,000)$.

Conclusion: effective counseling from health workers can increase the participation of husbands into contraceptive acceptors.
\end{abstract}

Keywords: age, education, income, knowledge, occupation, participation.

\section{INTRODUCTION}

Indonesia is a country seen from its population is in the fourth position in the world, with a relatively high growth rate. The essence of the Family Planning Program (KB) duties, in this case, is clear that reducing fertility in order to reduce the burden of development for the realization of happiness and prosperity for the people and the nation of Indonesia. [5]

Data from BKKBN of Banjarmasin city in 2014, from 350,000 users of contraceptives in South Kalimantan, IUDs were used by 11,434 people, 7,361 MOWs, MOP 2,129 people, 12,999 for condoms, 44,426 Implants, 220,304 people and 
313,501 injections. By 2015, out of 350,000 users of contraceptives in South Kalimantan, the Intra Uterine device (IUD) is used by 11,434 people, the Female Operation Method (MOW) is 7,361 people, the Male Operation Method (MOP) 2,129 people, for condom achievement 12,899, Implants 44,426 people, Pills 220,304 people and Injection 313,501 people. [3]

The Midwife of Independent Practice (hereinafter referred to as BPM) "N" is one of the practice midwives located in densely populated residential areas. BPM $\mathrm{N}$ has complete basic laboratory facilities for blood check (hematology) of patients, has ultrasound equipment for pregnant women, as well as receiving health insurance cards. BPM $\mathrm{N}$ serves maternal and child health services including maternity and maternal care, postpartum, counseling and family planning, infant and child development monitoring, infant immunization treatment and services, and may also provide examination and treatment (with Puskesmas doctors collaboration) with the elderly.

As a pomegranate midwife, midwife " $N "$ serves male and female KB acceptor. The data of a male KB acceptor in BPM N is unknown. Preliminary study results conducted in February-April 2016, as many as 9 people of fertile couples (90\%) of 10 couples of fertile age prefer hormonal contraceptives 3-month injection type is considered safer to prevent pregnancy with a long period of time. Though many problems arise and complaints of couples of childbearing age, ranging from increased weight, black spots and the appearance of acne on the face and body, the menstrual cycle is disrupted, until the emergence of various kinds of reproductive diseases such as cysts, uterine myomas to cancer.
Meanwhile, when asked about the problem of condom contraception, 9 out of 10 couples of childbearing age say fear of leaking, fear of pregnancy, illness during intercourse, to lack of comfort during sex, and as many as 9 men said feared to undergo male surgery method (MOP) and the cost is very expensive. Based on the above background, the authors are interested to conduct research on Factors Affecting Husbandry Participation Becoming Contraceptive Askseptor in BPM $\mathrm{N}$ Banjarmasin.

\section{METHODS}

In this study using analytical survey research method with a cross-sectional approach that aims to analyze the factors that influence the participation of husbands to become the contraceptive askseptor in BPM N Banjarmasin in one-time research. The population in this study were male fertile couples in BPM N Banjarmasin amounted to 97 counted from the last 3 months ie from February to April of 2016, while the sample in this study was taken using accidental sampling technique that is as many as 49 male couples of childbearing age who met by chance without any deliberate element in BPM N Banjarmasin during the research took place.

Variables taken in this study are age, education, occupation, income, knowledge and husband participation into contraceptive acceptors. The data will be analyzed using statistical test with chisquare to know the factors that influence the participation of husband to become acceptor of contraception. 


\section{RESULTS}

1. Univariate analysis

a. By Age

Age of respondents in BPM N

Banjarmasin can be seen in the following table:

Table 1 Frequency Distribution of Respondents by

\begin{tabular}{cccc}
\multicolumn{2}{c}{ Age } & & \\
\hline No. & Age & $\mathrm{f}$ & $\%$ \\
\hline 1 & $<25$ years & 14 & 28,6 \\
2 & 25-50 years & 31 & 63,3 \\
3 & $>50$ years & 4 & 8,1 \\
\hline & Total & 49 & 100 \\
\hline
\end{tabular}

The results showed that most respondents with age 25-50 years amounted to 31 people $(63.3 \%)$.

b. Based on education

Education respondents in BPM

$\mathrm{N}$ Banjarmasin can be seen in the following table:

Table 2 Respondent Frequency Distribution by Education

\begin{tabular}{cccc}
\hline No. & Education & $\mathrm{f}$ & $\%$ \\
\hline 1 & Basic & 20 & 40,8 \\
2 & Middle & 22 & 44,9 \\
3 & Higher & 7 & 14,3 \\
\hline & Total & 49 & 100 \\
\hline
\end{tabular}

The results showed that most respondents were 22 people (44.9\%) with medium education.

c. Based on Employment

The work of respondents in BPM

$\mathrm{N}$ Banjarmasin can be seen in the following table:

Table 3 Frequency Distribution of Respondents by employment

\begin{tabular}{cccc}
\hline No. & Employment & $\mathrm{f}$ & $\%$ \\
\hline 1 & Yes & 44 & 89,8 \\
2 & No & 5 & 10,2 \\
\hline \multicolumn{2}{c}{ Total } & 49 & 100 \\
\hline
\end{tabular}

The results showed that most respondents were 44 people $(89.8 \%)$.

d. Based on Income Income of respondents in BPM N Banjarmasin can be seen in the following table:

Table 4 Respondents Frequency Distribution by Income

\begin{tabular}{cccc}
\hline No & Income & F & $\%$ \\
$\cdot$ & $<\operatorname{Rp~2.085.000}$ & 26 & 53,1 \\
\hline 1 & $\geq \operatorname{Rp~2.085.000}$ & 23 & 46,9 \\
2 & Total & 49 & 100 \\
\hline \multicolumn{2}{l}{}
\end{tabular}

The results showed that most respondents ie 26 people $(53.1 \%)$ have income $<\mathrm{Rp} 2.085 .000 /$ month.

e. Based on Knowledge Knowledge of respondents in BPM $\mathrm{N}$ Banjarmasin can be seen in the following table:

Table 5 Frequency Distribution of Knowledge

\begin{tabular}{cccc}
\hline No. & Knowledge & $\mathrm{f}$ & $\%$ \\
\hline 1 & Less & 19 & 38,8 \\
2 & Enough & 17 & 34,7 \\
3 & Good & 13 & 26,5 \\
\hline & Total & 49 & 100 \\
\hline
\end{tabular}

The results showed that most of the respondents were 19 people (38.8\%) knowledgeable enough.

f. Based on the participation of husbands of contraceptive acceptors into Contraceptive Askseptor in BPM N Banjarmasin Participation of contraceptive acceptors husbands become Contraceptive Askseptor in BPM N Banjarmasin can be seen in the following table: 
Table 6 Frequency Distribution of Respondents' Participation

\begin{tabular}{cccc}
\hline No. & Participation & $\mathrm{f}$ & $\%$ \\
\hline 1 & No & 37 & 75,5 \\
2 & Yes & 12 & 24,5 \\
\hline & Total & 49 & 100 \\
\hline
\end{tabular}

The results showed that most of the respondents ie 37 people $(75.5 \%)$ did not participate as acceptors of family planning.

2. Bivariate Analysis

a. Influence of Age With Participation of the husband of contraceptive acceptors Being a Contraceptive Askceptor in BPM $\mathrm{N}$ Banjarmasin

Table 7 Influence of Age With Participation of the husband of contraceptive acceptors Being a Contraceptive Askceptor in BPM N Banjarmasin

\begin{tabular}{|c|c|c|c|c|c|c|}
\hline \multirow{2}{*}{ Age } & \multicolumn{4}{|c|}{ Participation } & \multirow{2}{*}{$\mathrm{f}$} & \multirow{2}{*}{$\%$} \\
\hline & No & $\%$ & Yes & $\%$ & & \\
\hline$<25$ & 12 & 24, & 2 & 14 , & 1 & 28, \\
\hline Years & & 5 & 2 & 3 & 4 & 6 \\
\hline $25-50$ & & & & 22 , & 3 & 63 \\
\hline Years & 24 & 49 & 7 & 6 & 1 & 4 \\
\hline $\begin{array}{c}>50 \\
\text { Years }\end{array}$ & 1 & 2 & 3 & 75 & 4 & 8 \\
\hline Total & 37 & $\begin{array}{c}75, \\
5\end{array}$ & 12 & $\begin{array}{c}24, \\
5\end{array}$ & $\begin{array}{l}4 \\
9\end{array}$ & 100 \\
\hline & & $=0$, & $<$ & & & \\
\hline
\end{tabular}

The result of research from 49 respondents is known that the respondent with age 25-50 years is the biggest respondent who does not participate as KB acceptor counted 24 people

The result of analysis with chi-square test obtained the result that $\mathrm{p}$-value $=0,041<\alpha=$ 0,05 or can be said that there is Influence of Age With Participation husband of contraceptive acceptors Become Contraception Askseptor at BPM N Banjarmasin. b. The influence of education with the participation of husbands of contraceptive acceptors become contraceptive Askseptor in BPM N Banjarmasin

Table 8 The influence of education with the participation of husbands of contraceptive acceptors become contraceptive Askseptor in BPM N Banjarmasin

\begin{tabular}{ccccccc}
\hline \multirow{2}{*}{ Education } & \multicolumn{5}{c}{ participation } & \multirow{2}{*}{ f } \\
\cline { 2 - 5 } & No & $\%$ & Yes & $\%$ & & \\
\hline Basic & 18 & 36,7 & 2 & 4,1 & 20 & 40,8 \\
Middle & 16 & 32,7 & 6 & 27,3 & 22 & 44,9 \\
Higher & 3 & 6,1 & 4 & 57,1 & 7 & 14,3 \\
\hline Total & 37 & 75,5 & 12 & 24,5 & 49 & 100 \\
\hline \multicolumn{7}{c}{$\mathrm{P}=0,041<0,05$} \\
\hline
\end{tabular}

Most of the basic educated respondents did not participate in the acceptor of $\mathrm{KB}$ amounted to 18

$$
\text { people }
$$

(36.7\%).

The result of analysis with chi-square test obtained the result that $\mathrm{p}$-value $=0,041<\alpha=$ 0,05 or can be said that there is the influence of education with Participation of husband of the acceptor of contraception become Askseptor of Contraception in BPM N Banjarmasin.

c. The Influence of Employment with Participation of a husband of a contraceptive acceptor becomes a Contraceptive Askseptor at BPM $\mathrm{N}$ Banjarmasin

Table 9 Employment with the participation of husbands of contraceptive acceptors becomes Contraceptive Askseptor in BPM N Banjarmasin

\begin{tabular}{|c|c|c|c|c|c|c|}
\hline \multirow{2}{*}{$\begin{array}{c}\text { Employmen } \\
\mathrm{t}\end{array}$} & \multicolumn{4}{|c|}{ Participation } & \multirow{2}{*}{$\mathrm{f}$} & \multirow{2}{*}{$\%$} \\
\hline & No & $\%$ & Yes & $\%$ & & \\
\hline No & 5 & $\begin{array}{c}10 \\
2\end{array}$ & 0 & 0 & 5 & $\begin{array}{c}10 \\
2\end{array}$ \\
\hline Yes & 32 & $\begin{array}{c}65, \\
3\end{array}$ & 12 & $\begin{array}{c}24 \\
5\end{array}$ & $\begin{array}{l}4 \\
4\end{array}$ & $\begin{array}{c}89 \\
8\end{array}$ \\
\hline Total & 37 & $\begin{array}{c}75 \\
5\end{array}$ & 12 & $\begin{array}{c}24, \\
5\end{array}$ & $\begin{array}{l}4 \\
9\end{array}$ & 100 \\
\hline \multicolumn{7}{|c|}{$\mathrm{P}=0,179>0,05$} \\
\hline
\end{tabular}


Most of the respondents who did not participate became KB acceptor amounted to 32 people $(65.3 \%)$.

The result of analysis with chisquare test obtained the result that $p=0,179>\alpha=0,05$ or can be said that there is no influence of work with Participation of husband of the acceptor of contraception become Askseptor of Contraception in BPM N Banjarmasin.

d. Influence of income with Participation of husband acceptor of contraception become Askseptor of Contraception in BPM N Banjarmasin

Table 10 Influence of income with Participation of husband acceptor of contraception become Askseptor of Contraception in BPM N Banjarmasin

\begin{tabular}{|c|c|c|c|c|c|c|}
\hline \multirow[b]{2}{*}{ Income } & \multicolumn{4}{|c|}{ Participation } & \multirow[b]{2}{*}{ f } & \multirow[b]{2}{*}{$\%$} \\
\hline & No & $\%$ & $\begin{array}{c}\mathrm{Ye} \\
\mathrm{s}\end{array}$ & $\%$ & & \\
\hline $\begin{array}{c}<\mathrm{Rp} \\
2.085 .000\end{array}$ & 22 & $\begin{array}{c}44, \\
9\end{array}$ & 4 & 8,2 & 26 & 53,1 \\
\hline $\begin{array}{c}>\mathrm{Rp} \\
2.085 .000\end{array}$ & 15 & $\begin{array}{c}30, \\
6\end{array}$ & 8 & $\begin{array}{c}16, \\
3\end{array}$ & 23 & 46,9 \\
\hline Total & 37 & $\begin{array}{c}75 \\
5\end{array}$ & 12 & $\begin{array}{c}24, \\
5\end{array}$ & 49 & 100 \\
\hline \multicolumn{7}{|c|}{$\mathrm{P}=0,115>0,05$} \\
\hline
\end{tabular}

Respondents who earned $<\mathrm{Rp}$ 2,085,000 / month mostly did not participate as family planning acceptors of 22 people $(44.9 \%)$. The result of analysis with chisquare test obtained the result that p-value $=0,092>\alpha=0,05$ or can be said that there is no influence of income with Participation of husband of the acceptor of contraception become Askseptor of Contraception in BPM N Banjarmasin.

e. The influence of knowledge with the participation of husbands of contraceptive acceptors become Contraceptive Askseptor in BPM $\mathrm{N}$ Banjarmasin

f.

Table 11 The influence of knowledge with the participation of husbands of contraceptive acceptors become Contraceptive Askseptor in BPM N Banjarmasin

\begin{tabular}{|c|c|c|c|c|c|c|}
\hline \multirow{2}{*}{$\begin{array}{c}\text { Knowledg } \\
\text { e }\end{array}$} & \multicolumn{4}{|c|}{ participation } & \multirow[b]{2}{*}{$\mathrm{f}$} & \multirow[b]{2}{*}{$\%$} \\
\hline & No & $\%$ & $\begin{array}{c}\mathrm{Ye} \\
\mathrm{s}\end{array}$ & $\%$ & & \\
\hline Less & 19 & $\begin{array}{c}38 \\
8\end{array}$ & 0 & 0 & 19 & 38,8 \\
\hline Enough & 17 & $\begin{array}{c}34 \\
7\end{array}$ & 0 & 0 & 17 & 34,7 \\
\hline Good & 1 & 2 & 12 & $\begin{array}{c}24 \\
5\end{array}$ & 13 & 26,5 \\
\hline Total & 37 & $\begin{array}{c}75, \\
5\end{array}$ & 12 & $\begin{array}{c}24, \\
5\end{array}$ & 49 & 100 \\
\hline \multicolumn{7}{|c|}{$\mathrm{P}=0,000<0,05$} \\
\hline
\end{tabular}

The less knowledgeable respondents mostly did not participate in the $\mathrm{KB}$ acceptor amounted to 19 people $(38.8 \%)$.

The result of analysis with chi-square test obtained the result that $\mathrm{p}=0,000<\alpha=0,05$ or can be said that there is the influence of knowledge with Participation of husband of the acceptor of contraception become Askseptor of Contraception in BPM N Banjarmasin.

\section{DISCUSSION}

Based on the results of research conducted on 49 respondents about Factors Affecting Husbandry Participation Becoming Contraceptive Askseptor in BPM N Banjarmasin obtained the following results: 
1. Univariate Analysis

a. Age of husband of the contraceptive acceptor in BPM N Banjarmasin.

Respondents aged 20-35 years had the largest number of 31 respondents $(63.3 \%)$, respondents with age $<20$ years were 14 people (218.6\%) and respondents with age $>35$ years were 4 persons $(8.2 \%)$. Respondents aged 25-50 years have the largest number. Respondents age 25-50 years physically reproductive health is more mature and is a measure of the level of maturity of a person. The increasing age of a person is said to mature in mind and behavior.

b. Education husband of the contraceptive acceptor in BPM N Banjarmasin.

The majority of respondents are 22 people $(44.9 \%)$ have medium education, 20 people $(40.8 \%)$ have basic education and 7 people $(14.9 \%)$ have a college education. The level of education of respondents who mostly educated middle and upper, very influential on knowledge, attitudes, and behavior of respondents to become $\mathrm{KB}$ acceptors in BPM N. Education can affect a person as well as a person's behavior or lifestyle especially in motivating to participate in the attitude of development. The level of education affect the changes in attitudes and healthy living behavior, higher education level will allow a person or society to absorb information about the family planning program, the benefits of family planning, contraceptives $\mathrm{KB}$ and implement it in the form of participation in family planning. [10] c. Occupation of the husband of the contraceptive acceptor in BPM N Banjarmasin.

Most of the respondents were 44 people $(89.8 \%)$ of respondents worked and 5 people $(10,2 \%)$ of respondents did not work. Someone who has more work spends more time working so less opportunity to find information about contraceptives, but not a few respondents who work to get contraceptives from coworkers so that respondents who work using contraceptives. [6]

d. The income of contraceptive husbands in BPM N Banjarmasin.

The majority of respondents ie 26 people $(53.1 \%)$ have income $<\mathrm{Rp}$ 2,085,000 / month and 23 people (46,9\%) have income < Rp 2,085.000 / month. This is consistent with the opinion of Notoatmodjo (2012), which states that socioeconomic is the social layers or position of different sizes of the level. So it is also recognized the general assumption that the size of ability for each class or layer in society is different. It can be concluded that socioeconomic affects the health status of the community, especially in couples of childbearing age in determining the selection of appropriate contraceptive and safe to use. The improved social economy will contribute to health maintenance where respondents are easily informed and family planning services are available to them. And the higher the family income the easier the family will get the 
information they want so that with the amount of information that can bring the insight of respondents.[10]

e. Knowledge of contraceptive husband in BPM N Banjarmasin.

Most of the respondents were 19 people $(38.8 \%)$ knowledgeable enough and 13 people $(26.5 \%)$ knowledgeable. Knowledge can be obtained from various sources such as print media or electronic media. Respondents in this study obtained information from health workers who provide information on family planning. With the counseling of the respondents who originally had less knowledge about family planning, knowledge increased in accordance with the information received.

The results of the study note that most respondents answered correctly about the question "Contraceptives in men also there are types of injections and pill tablets" as many as 38 people $(77.5 \%)$. Respondents know that in the types of contraceptives men can use, there are no contraceptive tools in the form of pills or injections. "Condoms are highly recommended for men who have a risk of transmission of viruses and venereal diseases" as many as 39 people $(79.5 \%)$. Most respondents know that condoms can prevent the risk of HIV transmission.

f. Participation of contraceptive acceptor husbands become Contraceptive Askseptor in BPM N Banjarmasin.

The majority of respondents ie 37 people $(24.5 \%)$ did not participate as family planning acceptors and 12 people $(24.5 \%)$ participated as FP acceptor. Participation is the tendency of a person's very high heart towards something from the outside and is very closely related to the heart of heart. Participation in this study was measured using a questionnaire of $\mathrm{KB}$ informed consent form and was measured only once. Participation of respondents to follow $\mathrm{KB}$ can be influenced by age, economic status, knowledge, education, and environment. [9]

Participation in berKB can be influenced by age, economic status, knowledge, education and environmental culture. This result means that the better the perception of the environmental culture as demonstrated by the ability to understand, believe and obey the norms and values prevailing in the community will strengthen the participation decisions in the Family Planning Program. Conversely, the less understanding, beliefs, and noncompliance with environmental culture will be lower participation in family planning programs. According to Le Guen in the journal Men's contraceptive practices in France: evidence of male involvement in family planning that men's participation in using contraception is said to be low at only $28.3 \%$ and $18.9 \%$ of them use condom contraception. This can be due to low income and education so that participation in or KB is still low. [8] Midwives should provide counseling to men to participate in using contraceptives. The better the counseling program is shown with a 
convincing explanation, giving the opportunity to ask, the explanation is easy to understand, the willingness to give explanations and done repeatedly will increase the participation of acceptors to join the family planning program. [4]

2. Bivariate Analysis

a. The influence of age on the participation of husbands of contraceptive acceptors become Contraceptive Askseptor in BPM N Banjarmasin.

The result of research from 49 respondents is known that the respondent with age 25-50 years is the biggest respondent who does not participate as $\mathrm{KB}$ acceptor counted 24 people $(49,0 \%)$. The result of analysis with chi-square test obtained the result that $\mathrm{p}$-value $=0,041<\alpha=0,05$ or can be said that there is Influence of Age With Participation husband of contraceptive acceptors Become Contraception Askseptor at BPM N Banjarmasin.

Age 25-50 years and over is the age that is considered very mature and their decision in participating using contraception. In terms of psychological, age 25-50 years is an easy age to absorb a variety of information about contraception.

This is in line with the research conducted by Ditta, et al about the relationship of knowledge and attitude with husband participation in family planning by 2015 based on respondent's characteristic seen from the age most are the respondents aged 20-35 years as many as 52 people $(60.5 \%)$. Age can affect the level of knowledge of a person because it is possible the more mature a person's age the more the experience gained then the level of knowledge owned the better. Age range 20-35 years old shows reproductive age and can be said young husband, so it can mean that the husband has enough experience so as to increase the level of knowledge. [4]

b. The influence of education with the participation of husbands of contraceptive acceptors become Askseptor Contraception in BPM N Banjarmasin.

Most of the basic educated respondents did not participate in the acceptor of $\mathrm{KB}$ amounted to 18 people (36.7\%). The result of analysis with chi-square test obtained the result that p-value $=0,041<\alpha=0,05$ or can be said that there is the influence of education with Participation of husband of the acceptor of contraception become Askseptor of Contraception in BPM N Banjarmasin. Education influences a prospective acceptor to choose the method of contraception used. The higher the education the higher the knowledge so that the acceptors can make the best decisions.

The level of education affect the changes in attitudes and behavior of healthy living, higher education level will allow a person or society to absorb information about the family planning program, the benefits of family planning, contraceptives $\mathrm{KB}$ and implement it in the form of participation in family planning. [4] 
c. Influence of work with Participation of husband of the acceptor of contraception become Askseptor of Contraception in BPM N Banjarmasin.

Most of the respondents who did not participate became KB acceptor amounted to 32 people $(65.3 \%)$. The result of analysis with chi-square test obtained the result that $p=0,179>\alpha$ $=0,05$ or can be said that there is no influence of work with Participation of husband of contraceptive acceptors Become Contraception Askseptor at BPM N Banjarmasin. In addition, the vasectomy method is still less familiar to the respondents. This can be seen from almost half of respondents knowledgeable that vasectomy can reduce male virility, there are still respondents are wellinformed that vasectomy is not onlyonly done once a lifetime and still respondents who do not know a vasectomy is one of the methods of male contraception.

Characteristics of respondents based on the work are expected to determine the pattern of communication and interaction between individual groups, people with broader interactions expected to add experience that can be used in the formation of knowledge.

d. Influence of income with Participation of husband acceptor of contraception become Askseptor of Contraception in BPM N Banjarmasin.

Respondents who earned $<\mathrm{Rp}$ 2,085,000 / month mostly did not participate as family planning acceptors of 22 people (44.9\%). The result of analysis with chi-square test obtained the result that $\mathrm{p}$-value $=$ $0,092>\alpha=0,05$ or can be said that there is no influence of earnings with Participation of husband of contraceptive acceptors Become Contraception Askseptor at BPM N Banjarmasin.

This research is supported by observation during the research where the average citizen who entered the working area of BPM N work as a market laborer. In addition, most of the residents are migrants from outside Borneo island who have no permanent jobs. Other residents' jobs are traders and factory workers. Socioeconomic is the economic balance affecting a person to meet the necessities of life. In this case, the respondents said that even low socioeconomic but still can utilize to use the use of contraception for Keehan self and family health. This means that the social economic layer is different in level or position of each economic group. [6]

e. The influence of knowledge with the participation of husbands of contraceptive acceptors become Askseptor Contraception in BPM N Banjarmasin

The less knowledgeable respondents mostly did not participate in the KB acceptor amounted to 19 people $(38.8 \%)$. The result of analysis with chi-square test obtained the result that $\mathrm{p}=0,000<\alpha=0,05$ or can be said that there is the influence of knowledge with Participation of husband of the acceptor of contraception become Askseptor of 
Contraception in BPM N Banjarmasin.

The fundamental issue in the implementation of the development of a men's participation program for the realization of equity and gender equality is in the form of changes in awareness, attitudes, and behavior of men/husbands and wives about family planning and reproductive health. From the observation of various surveys in some provinces, the level of knowledge of men on family planning is generally low, the factors that influence, among others: education, employment, exposure to mass media, environmental conditions, experience using contraceptives and other factors. The role of gender equality, when women and men have equal participation in decision-making and resource control, and similar values and treatment, have been shown to have a positive effect on maternal and child health outcomes.

This research is in line with research conducted by Riyanti in Kelurahan Pahandut Seberang Palangka Raya using Person Product Moment test showed that there is a significant positive correlation between knowledge with participation (p $<0,05$ and correlation coefficient value $\quad 0,318$ ).

The involvement of men in using contraception is influenced by the health education delivered by counselors, so the counselor needs to understand that behavioral change is a process that takes place in the development stage of knowledge to take a decision. [2]

\section{CONCLUSION}

Based on the results of the discussion in research on Factors Affecting Husbandry Participation Becoming Contraceptive Askseptor in BPM N Banjarmasin, it can be concluded that most respondents aged 25-50 years amounted to 31 people (63.3\%), most respondents ie 22 people $(44,9 \%)$ have medium education, the majority of respondents are 44 people $(89,8 \%)$ respondents work, most of the respondent is 26 people $(53,1 \%)$ have income <Rp 2,085.000 / month, most of respondent 19 people $(38,8 \%)$ are knowledgeable enough, most of the respondent that is 37 people $(24,5 \%)$ did not participate become KB acceptor. There is the influence of age, education and knowledge with husband participation of contraceptive acceptors become contraceptive Askseptor in BPM N Banjarmasin and there is no influence of work and income with Participation of husband of the acceptor of contraception become Askseptor of Contraception in BPM N Banjarmasin. 


\section{REFERENCES}

[1]. Anurag Mishra, dkk. Men's attitudes on gender equality and their contraceptive use in Uttar Pradesh India. Published online 2014 Jun 4. doi: 10.1186/17424755-11-41. PMCID: PMC4051668

[2]. Berhane, dkk. 2015. Male involvement in family planning program in Northern Ethiopia: an application of the Transtheoretical model. Patient Educ Couns. 2015 Apr;98(4):469-75. doi: 10.1016/j.pec.2014.12.012. Epub 2015 Jan 14.

[3]. BKKBN. 2015. Peningkatan Partisipasi Pria dalam Keluarga Berencana dan Kesehatan Reproduksi di Indonesia.BKKBN Banjarmasin

[4]. Ditta Tourisia, Sumarah, Hartini. Hubungan Pngtahuan dan Sikap dngan Partisipasi Suami dalam Br KB. Jurnal Involusi Kbidanan Vol 5 N0 9 Jan 2015 Hal 50-64

[5]. Hartono, P. 2011. Laju Pertumbuhan Penduduka. Jogjakarta: Nuha Media.

[6]. Ika Apriyanti. 2009. Hubungan Tingkat Pengetahuan suami dengan keikutsertaan suami dalam KB Di Desa Karangjati Sragen.
[7]. Ken Sudarti, Puji Prasetyaningtyas. Peningkatan Minat Dan Keputusan Berpartisipasi Akseptor Kb. Jurnal Dinamika Manajemen. JDM Vol. 2, No. 2, 2011, pp: 130-138

[8]. Le Guen M, dkk. 2015. Men's contraceptive practices in France: evidence of male involvement in family planning. Contraception. 2015 Jul;92(1):46-54. doi: 10.1016/j.contraception.2015.03.011. Epub 2015 Mar 26

[9]. Notoatmojdo, Soekidjo. 2012. Pendidikan Dan Perilaku Kesehatan. Jakarta: RinekaCipta

[10]. Riyanti. (2005). Hubungan Pengetahuan dan Sikap Suami Terhadap Partisipasi Pria dalam Pelayanan KB di Kelurahan Pahandut Seberang Palangka Raya. KTI, FK UGM 